University of Wollongong

Research Online

Faculty of Business - Papers (Archive)

Faculty of Business and Law

2013

Indigenous identity in the nation brand: tension and inconsistency in a nation's tourism advertising campaigns

Alan Pomering

University of Wollongong, alanp@uow.edu.au

Follow this and additional works at: https://ro.uow.edu.au/buspapers

Part of the Business Commons

Research Online is the open access institutional repository for the University of Wollongong. For further information contact the UOW Library: research-pubs@uow.edu.au 


\title{
Indigenous identity in the nation brand: tension and inconsistency in a nation's tourism advertising campaigns
}

\begin{abstract}
The purpose of this paper is to discuss one nation's attempts at tourism branding in which elements of Indigenous identity featured as a key element of the brand, arguably impairing persuasion results. The methodology follows a qualitative and interpretivist approach. A recent tourism advertising campaign for Australia is described; observations are made regarding Indigenous Australian identity in relation to the broader national identity; recent international tourist arrival trends are discussed; and connections between this triad are proposed. The campaign under study is also compared with proximate campaigns. The study raises questions about tapping a contested national identity for tourism branding purposes, and comments on the pitfalls of inconsistency in brand positioning, drawing on available tourism data to support the discussion. The study contributes by examining nation brand from a marketing communications perspective where exaggerated identity claims are argued to undermine perceived brand image. The use of secondary tourist arrival data to support our thesis is a limitation of the study and must be seen in the phenomenological light of the overall discussion. We conclude with suggestions for further research.
\end{abstract}

\section{Keywords}

identity, tourism, advertising, campaigns, nation, brand, tension, inconsistency, indigenous

\section{Disciplines \\ Business}

\section{Publication Details}

Pomering, A. (2013). Indigenous identity in the nation brand: tension and inconsistency in a nation's tourism advertising campaigns. Corporate Reputation Review, 16 (1), 66-79. 


\title{
Indigenous Identity in the Nation Brand \\ Tension and Inconsistency in a Nation's Tourism Advertising Campaigns
}

\begin{abstract}
The purpose of this paper is to discuss one nation's attempts at tourism branding in which elements of indigenous identity featured as a key element of the brand, arguably impairing persuasion results. The methodology follows a qualitative and interpretivist approach. A recent tourism advertising campaign for Australia is described; observations are made regarding Indigenous Australian identity in relation to the broader national identity; recent international tourist arrival trends are discussed; and connections between this triad are proposed. The campaign under study is also compared to proximate campaigns. The study raises questions about tapping a contested national identity for tourism branding purposes, and comments on the pitfalls of inconsistency in brand positioning, drawing on available tourism data to support the discussion. The study contributes by examining nation brand from a marketing communications perspective where exaggerated identity claims are argued to undermine perceived brand image. The use of secondary tourist arrival data to support our thesis is a limitation of the study and must be seen in the phenomenological light of the overall discussion. We conclude with suggestions for further research.
\end{abstract}

\section{Key words}

Advertising, Australia, Indigenous identity, nation branding, national identity, tourism.

\section{Introduction}


Nation branding, given the multi-faceted identity of the nation: its history, politics, geography, economy, technology and culture, and its current societal management, is a precarious task. The concept of nation is a convenient yet curious one; its union may reside more in the imagination or international agreement than the collective psyche of those sharing a politically-defined physical space. As Anderson (1983) notes, "members of even the smallest nation will never know most of their fellow members, meet them, or even hear of them, yet in the minds of each lives the image of their communion" ( p. 15). This imagined communion is an oft-described feature of the notion of nation. Bennett's (1993) nations of imagined communities are represented in the form of "long, continuous narratives" or "never-ending stories" (p. 74), while Appadurai's (1996) nations of imagined worlds are "constituted by the historically situated imaginations of persons and groups spread around the globe" (p. 33).But these narratives are not always continuous and nations are not always peopled by a communion. Europe's Age of Discovery disrupted nations and peoples in the New World. Today, these New World nations consist of various peoples, in the minds of some of whom may not live the image of a national communion.

The purpose of this paper is to discuss one such nation, where a recent attempt at nation branding by the national tourism destination marketing organisation, featuring elements of Indigenous identity in its international tourism advertising campaign has possibly achieved sub-optimal results. The national tourism brand is argued to offer a valuable nation branding context, as the vacation purchase decision is typically a high-involvement, discretionary purchase decision for the different targeted markets' consumers, and therefore it might be considered a microcosm of nation branding in general. 
The aim of national tourism branding is to construct a favorable perception of the nation destination, that is, a positive national destination brand image, from the consumer's perspective, to differentiate and build preference for that nation among competing destination brands. Along with elements of the landscape, built or natural, national social and cultural identity is often included as an element of the nation brand. Identity elements should be built on the positive characteristics of the brand, and should proffer the tourism consumer a clear personal benefit: the destination promise. But a nation, particularly a modern and multi-cultural nation, offers a “fragmented set of images” (O’Shaughnessy and O’Shaughnessy, 2000, p. 58), making the choice of which fragments to employ a critical decision for the brand manager. In situations where Indigenous national identity fragments are contentious, as is the case with Australia's Indigenous population, the Aborigines, this is particularly poignant. In this paper the portrayal of Indigenous identity will be seen to be a problematic marketing communications approach. Tension surrounds Indigenous identity in its use as an aspect of the Australia nation brand, particularly as the brand is typically, and perhaps even unwittingly, constructed through the lens of the dominant, non-indigenous culture.

Further highlighted in our discussion is the point that a clear and consistent positioning of the brand is a perquisite for branding success. Van Rekom (1997) has described the desired identity of the brand as that which the brander wants to get across to its audience, but this desired identity may be at odds with the brand's real identity, that is, what it is in reality. A risk for branders is therefore changing the desired identity too quickly, or too regularly, without backing up this projected brand 
identity with substantial change to the brand's claimed attributes and benefits. Such unsubstantiated brand claims risk not being successful in promoting the desired brand image perceptions. Repositioning of a brand, particularly one as conspicuous as a nation's tourism destination brand, is therefore a high-risk challenge for brand managers. We situate Australia's recent Indigenous identity tourism branding campaign, Come Walkabout, in relation to the campaigns that preceded and followed it in order to highlight this strategy's perils.

The paper proceeds as follows. In the next section we discuss some of the issues of the national identity, and in particular the national identity of Indigenous Australia and the use of Indigenous identity as an element of a nation's tourism brand. We then review key advertisements of Australia's recent tourism advertising campaign, one that features this Indigenous identity as its centrepiece, and then contrast this campaign's executional style and creative idea with the campaigns that preceded and followed it. The campaign's broad results, in terms of overall visitor numbers in key markets, are examined, drawing on available secondary data, and research findings in regard to Indigenous Australia as a tourism drawcard are reviewed and commented on in relation to current market trends. The limitations of our approach are discussed, and we conclude with suggestions for future research in this area.

\section{National Identity}

As noted above, a nation's identity is often presumed to be collective and continuous one. Where identity is contested, however, as it is in the case of Australia, this understanding of communion and continuity is questioned. The notion of nation as a 
'fragmented set of images' is perhaps more accurate, especially for the modern multicultural expression of groups gathered beneath one flag. This has also rung true for former states that were artificially and perhaps arbitrarily joined together but have recently broken apart along lines of old allegiances and/or ethnic groupings: the former USSR and Yugoslavia are notable examples. In post-colonial nation settings, the selection of fragmented images to project the nation's brand requires considerable care. In 'new-world' nations, like the countries of North and South America, South Africa, New Zealand, and Australia, the growth of multiculturalism as a result of early colonialism and subsequent immigration flows has resulted in an Indigenous population perhaps occupying an increasingly marginalised space and sense of identity. For these Indigenous communities, any sense of a national identity may be far from a shared one.

\section{National Identity of Indigenous Australia}

Australia's Indigenous peoples lost sovereignty over their lands from 1788 onwards, as a result of colonial settlement. Unlike the situation with New Zealand's Maori peoples, who signed a formal treaty with their colonial invaders, The Treaty of Waitangi of 1840 (www.nzhistory.net.nz), which has delivered the Maori a much more prominent place in contemporary New Zealand society, Australia's Indigenous peoples continue to struggle against the British legal fiction of terra nullius, or empty land. The nation's current Intervention strategy by Australia's Federal Government, which is reportedly designed to protect Indigenous children and to ensure funds allocated for their welfare are used for that purpose, has been criticized by the United Nations for breaching a number of international treaties and even being a racist policy (Australian Broadcasting Commission, 2009). 
It was not until 1967, when an overwhelming $90.7 \%$ of the non-indigenous Australians allowed to vote agreed to a more theoretically equal social status for Indigenous Australians finally recognising the first Australians as citizens of the new Australian nation. Still, however, Indigenous identity sits uncomfortably alongside the dominant, colonial culture that began to affect it in 1788. Indeed, when the new Australian nation called for celebration of its bicentenary in 1988, Indigenous Australia commemorated the 200 years of invasion instead. Countering the mainstream celebrations of two centuries of white settlement were fringe protests of 'White Australia has a Black History’ and ‘40,000 Years Don’t Make a Bicentenary', often in the form of graffiti and adorning T-shirts.

Indigenous Australian identity proves difficult to reconcile. Urry (1992) observed scathingly that prior to Australia's Bicentenary, Indigenous Australians were looked upon as "social pollutants" that "make certain places appear contaminated and unsuitable for visual consumption", but became "part of the exotic or 'traditional' attractions ...when the Australian government found it necessary to initiate some hasty measures to compensate the Aborigines for years of neglect" (p. 182). Almost a decade later, Craik (2001) argued Australia has faced a problem of "packaging and managing simultaneously the unique qualities, exotic elements and everyday life for the tourist gaze, a challenge that is more difficult in a culture that is the object of colonial and postcolonial exploitation" (p. 109).

Accounting for less than five percent of the nation's population, but over-represented in such statistics as incarceration rates, deaths in custody, infant mortality, early and 
preventable deaths, general morbidity and unemployment, and generally underrepresented in the nation's success indices (Australian Human Rights Commission, 2008), Australia's Indigenous peoples occupy an unenviable position in the nation's communion. This is not to say that Indigenous Australia has not produced its share of national success stories: doctors, lawyers, business people, activists, artists, war heroes, and humanitarians: overall however, the statistics point to a segment of the nation that tends to miss out on the nation's riches and does not have an equal voice in the nation's political decision-making. This post-colonial legacy accounts for how images of Indigenous Australia may be appropriated, and perhaps embellished, by the dominant national culture for what Urry (1992) has referred to as the tourist gaze.

\section{Indigenous Identity as Nation Tourism Brand}

Tourism might be used to highlight and even foster the development of Indigenous members of a multicultural nation and their culture. Pitchford (2008), for example, has explored how the Welsh, a marginalised, old-world ethnic group, have used tourism to help reclaim their sense of national identity. Such identity tourism, she concludes, is "emancipatory", raising political questions about "whose identity is represented and how, and the locus of control over ethnic heritage development; and interpretation" (p. 3). This contest of power over identity portrayal is why Morgan, Pritchard and Pride (2004) argue contemporary place branding is "not simply a rational marketing activity: it is also a political act" (p.8). It is a political act typically characterised by dominant groups controlling the identity imagery of subordinate groups (Morgan and Pritchard, 1998). Such is certainly the case with tourism's portrayal of Indigenous Australia's identity, the focus of this paper. 
Subordinate ethnic groups, such as Australia's Indigenous Aborigines, may play the role of a "sub-brand" (Morgan, Pritchard and Pride, 2004, p. 71) in the nation destination's overall brand architecture. Native Americans, for example, may be considered a sub-brand of the nation brands of Canada and the United States of America, and have often featured in branding communications to portray a link with these nations' Indigenous cultural past, seemingly ignoring the disruption of the national narratives that came about as a result of colonial invasions. Pitchford (2008) highlights the popularity of such nation brand elements, commenting that although they "continue to be stereotyped as poor and backward, yet their traditions are also greatly appealing to many" (p. 12). New Zealand's Maori, though a colonised and subordinate ethnic group, have been relatively successful in asserting their national identity as a major sub-brand of New Zealand (Morgan, Pritchard and Pride, 2004). The national identity of the Maori, recognised and respected through Treaty of Waitangi of 1840, plays a key role in New Zealand's very successful New Zealand 100\% Pure campaign (Morgan, Pritchard and Piggott, 2002). The success of its sportspeople, such as the All Blacks rugby team, and the prominent place of the Maori people and their culture in contemporary New Zealand society have worked to add leverage to the campaign. Indigenous Australia's identity, however, stands in stark contrast to the story of the neighbouring Maori.

Hummon (1988) has argued that tourism branding campaigns often attempt to create an image of an 'extraordinary world', where the ordinary day-to-day tasks and obligations of our lives are replaced by an inverted social ritual of freedom and play. A risk for tourism brand managers is to showcase an extraordinary destination that departs too far from the ordinary of what the destination might typically deliver. 
Over-promising is a cardinal mistake of marketing communications, resulting in either ineffective advertising communications that fail to have an impact on international tourism consumers' decision-making, or disappointed tourists, likely to spread negative word-of-mouth about the destination within their social networks. Where the portrayed of national identity does not sit comfortably with reality, audience members may be left with confusion and dissonance. A sub-optimal brand image may ensue.

\section{Methodology}

Given the number of push and pull variables that might influence the response to an international tourism branding campaign it is extremely difficult to attribute particular effects to particular causes. The approach we take here is therefore a qualitative and interpretivist one (Snape and Spencer, 2003), making a theoretical case for the conclusions we draw about Indigenous identity portrayal in nation branding when that identity is a contested one, and the perils of inconsistency, in marketing communications message and tone, in attempting to position a nation brand. We draw on secondary data, that is, Australia's international visitor arrivals over a ten-year period, from which we infer potential problems with the nation's branding attempts, and estimates of the percentage of different nations' visitors that report their decision to visit Australia being influenced by Aboriginal culture. We acknowledge that relying on such data is an unscientific approach, but refer to the data to highlight potential and general explanations only rather than infer direct cause-and-effect. We believe this approach provides some but limited support for discussion of the topics at hand, and the reader will keep this limitation in mind as he or she considers the points raised. 


\section{Come Walkabout: Indigenous Identity in Nation Tourism Branding}

A nation's economic prosperity may, in part, depend on how successfully its perceived advantage as a tourism destination is communicated to key tourist markets. Australia's Tourism Forecasting Committee, for example, expected more than six million international arrivals in 2011, which were to generate exports of A $\$ 26$ billion, or around nine percent of total export revenues (Department of Resources Energy and Tourism, 2011). National destination marketing organisations, such as Tourism Australia, expend considerable financial resources in an attempt to position the nation as a favourable destination, and it is important that such positioning efforts provide a return on the investment. As Craik (2001) has noted, tourism may serve as a point of coordination for national identity and culture in order to provide economic stimulus.

Australia's recent national tourism advertising campaign, Come Walkabout, attempted to capitalise on international exposure to the movie, Australia. The perceiver might easily be left wondering just what is brand Australia, however, as the campaign, which featured an Indigenous Australian actor from the Australia movie, was a major departure from the advertising campaign that preceded it, and that which was to follow it. Rather than asking prospective international visitors "Where the bloody hell are you?", as the previous campaign had controversially done, the Come Walkabout campaign was an attempt at a more sophisticated conversation with key markets' bigspending tourists. Whereas the previous campaign had used a humorous appeal, one that caused offence through the use of "bloody hell" in the UK, Canadian and several 
Asian markets, the Come Walkabout campaign sought to move the nation's appeal upmarket using a grander, more cinematic advertising style and more thoughtful tone.

Though Indigenous Australians count among their number successful athletes, artists, doctors, lawyers, teachers and politicians, the imagery that is typically relied upon to represent Indigenous Australia's 'fragments of the extraordinary' typically features painted, semi-naked bodies performing dance or traditional ritual. This seems to be a throw-back to a 1966 report (Harris, Kerr, Forster and Co., 1966) which recommended that Indigenous Australia could provide a unique national tourism attraction. Co-incidentally, the same report recommended direct government funding of Australia's tourism promotion for the first time.

In the Australia movie-inspired tourism advertising campaign, which was conducted in more than 20 key international markets from October 2008 to mid-2009, print and other media centred round the platform of two short cinematic film-like commercials. These commercials were for English-speaking Asian and North American audiences, and focused on "contemporary people who are stressed and disconnected from their loved ones and their true selves, and who find their centre and their release in Australia" (Tourism Australia, 2008). The motivational appeal employed was an oftused one: through tourism will come personal renewal and re-creation, but it was hoped the movie's popularity at the box office might give the appeal renewed vigour and focus. The medium delivering the promise of renewal and recreation from a holiday in Australia is the young Indigenous actor from the Australia movie, Brandon Walters. In one of the campaign's two main television commercials aimed at the North American market, harking back to ideas of the noble savage, a half-naked 
Walters inexplicably enters the apartment of a troubled, semi-conscious female executive, worn out and over-stressed by today's ordinary rituals of work, and casts a handful of shimmering dust into the air above her. The creative device is seemingly borrowed from the pixie dust of Disney's Magic Kingdom and is accompanied by whispers to her of the benefits of sometimes losing oneself, and going Walkabout. The version of the ad for Asian market follows a similar line, but with a male executive. Each ad closes with each executive rejuvenated and, in the company of their romantic partner, shown relaxing against the backdrop of the remote Australian landscape, a backdrop that is associated closely with Indigenous Australia.

The idea of going Walkabout is associated with Indigenous Australians' intricate connection with the land: "Travelling their respective country and understanding every aspect of the landscape is a uniquely Aboriginal tradition that non-indigenous observers named 'walkabout'. To go walkabout in the $21^{\text {st }}$ century is to escape from the pressures of everyday life and to reconnect with yourself, with loved ones, and with the natural world" (Tourism Australia, 2009). The term 'walkabout' is an imposed one, assigned within the dominant colonial culture to describe a ritual of movement though the landscape that was little understood by those who began to disrupt much of Indigenous Australians' connection with the land when white settlement began in 1788 .

In spite of the $\$ 40$ million budget behind the campaign, this new branding approach risked being ineffective for a number of reasons. Firstly, the portrayal of Indigenous identity might have been perceived as incongruent with international consumers' prior Australia brand beliefs. This information-processing phenomenon is explained by 
cognitive response theory (Wright, 1973), which argues that prior beliefs are likely to be drawn upon in evaluating new informational inputs. Australia's colonial past and the ongoing lack of reconciliation with the country's Indigenous peoples, the latter highlighted by several high-profile deaths of Aboriginal community members while in police custody, which have featured in recent world news reports, might be expected to influence potential tourists' nation brand Australia schemas. Ironically, the notion of Walkabout underscoring this advertising campaign and the outmoded depiction of Walters' character might be expected to create dissonance with more culturally-aware prospective visitors to Australia. That is, the real and ordinary fragments of Indigenous identity that is the ordinary world of nation brand Australia, may conflict in prospective tourists' minds with the extraordinary tourist world of the Come Walkabout (desti)nation branding campaign.

The Come Walkabout campaign achieved considerable global exposure, potentially arousing this cognitive conflict across a wide swath of potential tourism brand Australia consumers. According to Tourism Australia's 2008-9 Annual Report (Tourism Australia, 2009a),

"More than 121 million experience seekers had the opportunity to see Tourism Australia's brand advertising in 14 countries, the majority seeing the campaign via more than one channel: television (70 per cent), online (58 per cent), print (11 per cent) and cinema ( 6 per cent). The online brand component appeared 92 million times in the UK and the USA alone. Visitation to the website australia.com increased 95 per cent from December 2008. Around 130 organisations worked in collaboration with Tourism Australia to deliver its promotion programs, including travel agents, Aussie Specialists, wholesalers and affinity partners such as 20th Century Fox, Canon, News Ltd and Virtuoso. More than 1,100 Aussie Specialists completed campaign module training to give them the necessary knowledge and resources to meet consumer demand for movie-inspired holidays. Almost 1,750 articles were generated within key media channels that were distributed to a combined audience of 3.4 billion people. Independent evaluation reveals that 86 per cent of these articles leveraged the 'Come Walkabout' campaign." 
The number of international arrivals to Australia in 2009 was 5.6 million, unchanged relative to the previous year. During 2010, the total number of international visitors rose to 5.9 million, a five percent increase over 2009. During 2010, however, there were decreases in numbers arriving from the United Kingdom, Germany, the United States, and Canada, but increases from New Zealand, France, South- and North-East Asia. During 2011, there were 5.9 million visitor arrivals, a decrease of 0.2 relative to the previous year (Australian Bureau of Statistics, 2012). There were falls across major European markets, with the UK, Germany and France down 5.9, 3.9 and 3.4 percent, respectively, while the US and Canadian markets were both down 3.4 percent. Japan, South Korea and Taiwan were down 16.4, 7.5 and 3.1 percent, respectively, but some of these falls were offset by growth in the Chinese, Indonesian and Indian markets, up 19.4, 13.2 and 6.8 percent, respectively (ABS, 2012). Tourist numbers to Australia include overseas students studying in Australia, and while this might throw confusion into the analysis of the nation's visitor statistics, it might be presumed that, with some qualification, such as university reputation, similar criteria affect students' place-to-study decision as affect tourists' international holiday destination decisions. In 2010, almost half a million international students were studying in Australia on a student visa, the majority of which were from South- and North-East Asia (Studies in Australia, 2011).

Interpretation of these figures is beyond the scope of this paper, however, the effectiveness of the Come Walkabout campaign might be questioned, given, in particular, the small impact on international arrivals and the slump in several key markets. The effects of the global financial crisis and other demand-side issues cannot 
be ruled out, of course, but more detailed tracking results, which would allow measurement of the campaign's effects on international arrivals on a market-bymarket basis and take into consideration specific geographic market effects, are, unfortunately, unavailable from Tourism Australia, the organization responsible for managing Australia's tourism brand. Mindful of this limitation, we now turn to the issue of Australia's inconsistent nation brand positioning, the second factor that we suggest is likely to lead to reduced branding effectiveness.

\section{Why Are they not Buying Our Brand?}

The Come Walkabout campaign followed what was perhaps Australia's most contentious tourism branding campaign ever, the campaign that asked the question as its tagline, So where the bloody hell are you?. This campaign, delivered to the world at a cost of more than $\mathrm{A} \$ 180$ million (Australian Broadcasting Commission), considerably more than the Come Walkabout campaign, was described by the Australian Prime Minister of the day, Kevin Rudd, as a "rolled gold disaster", which had failed to yield any significant benefits for the tourism industry (Sydney Morning Herald, 2008). In this campaign, audiences were told that preparations had been made for their visit: the crocodiles had been removed from the nation's swimming pools and the kangaroos had been removed from the golf courses. Half-naked Indigenous Australians, their bodies painted in ceremonial designs, were featured performing traditional dance with the voiceover, "and we've been rehearsing for over 40,000 years", followed by the tagline question, effectively asking why overseas tourists were not buying the Australian holiday experience on offer. How, Australian tourism branders wanted to know, could overseas travelers not take up the opportunity to travel south and enjoy the benefits of such earnest preparations? 
Unfortunately, despite its quite considerable budget, the campaign was initially banned in the UK for being profane and in Canada for promoting alcohol consumption, and was criticized by the American Family Association (Dwyer, 2010). A risk with the campaign was the use of humour, which, as it is often based on subtle nuances in language and culture, is difficult to communicate effectively across cultures. International audiences simply might not have understand the playfulness of, for example, needing to remove crocodiles from the nation's swimming pools, or the colloquial use of "bloody" to provide emphasis to the question's inquisitiveness.

Come Walkabout was pitched at a more sophisticated segment of the market, and was something of an admission that the Bloody Hell campaign had got the nation branding wrong. But the leverage it was hoped the campaign would receive from the movie Australia failed to materialise as the movie did not meet expectations at global box offices. The campaign that followed continued with the inconsistent branding. Possibly wishing to emulate the state of Queensland's Best Job in the World campaign, which made successful use of social media and interactive marketing, more or less shunning mass media for its tourism promotion, the campaign that followed went for a completely different approach. We will briefly describe this campaign in the next section.

\section{Post-Come Walkabout}

The Come Walkabout campaign was the third global advertising campaign within a period of five years promoting Australia as a tourism destination. It was replaced in 2010. Oprah Winfrey was enticed to tour Australia and broadcast her popular 
television program from Downunder. In a departure from the aforementioned 1966 report that had pushed for Indigenous Australia to be showcased to promote the nation to the world as a tourist destination, an African American was to replace Australia's Indigenous fragments of national identity in order to resonate with the US market. A further feature of the campaign, replacing creative strategy with interactivity, was the invitation to consumers to submit their views on why "There's nothing like Australia", in an effort to move the nation's tourism branding into the world of social networks.

\section{Impacts of the Come Walkabout Campaign}

In order to understand the impacts of Come Walkabout and consecutive campaigns, Table 1 provides a snapshot of international tourist arrivals to Australia from 2000, when Australia attracted much international focus through Sydney's hosting of the summer Olympic Games, to 2011. Over this period of time, it is interesting to note that Australia had by 2010 slipped from its rank of 31 to 36 on total global tourist arrivals (Nationmaster, 2011 ). It is, of course, impossible to attribute visitor number movements to a single campaign, given the impact of such external influences as competitors' marketing and branding activities, and at a time of financial crisis affecting parts of the globe disproportionately, nevertheless inferences might be drawn from the following observations.

\section{Insert Table 1 here.}


As Australia's tourism marketers have struggled to achieve a meaningful and consistent positioning for the nation as an international tourism brand, the Australian national identity, a selling point of nation branding campaigns, has struggled to move from a colonial to a postcolonial outlook and appropriately accommodate the place of Indigenous Australians and their culture in contemporary Australian life. As Anholt (2007) has argued, "When governments have a good, clear, believable and positive idea of what their country really is, what it stands for and where it's going, then they stand a good chance of building and maintaining a competitive national identity both internally and externally" (p. 26). This clear idea is absent in Australia, exemplified by the current Government's unreadiness to trust the nation's people with the question of whether the nation's Indigenous peoples should achieve the same rights as other Australians under the nation's constitution.

To be successful, Chernatony and MacDonald (2003) argue that the brand, whether a product or service, place or person, must be augmented in a way that permits the consumer to see sustainable added values that closely match their needs. Macrae, Parkinson and Sheerman (1995) note that the brand's characteristics and added values that appear relevant to consumers might be functional or non-functional, their awareness of which may be conscious or intuitive. Branding, it follows, is the orchestrated attempt to communicate this brand-linked relevance and meaning to key audiences, and nation branding might be seen as an attempt to link such relevance and meaning to a nation state. The inability to achieve a sophisticated and mature depiction of Indigenous Australian identity, and therefore Australian identity, as reflected in these recent tourism campaigns, has undermined the effectiveness of such 
advertising efforts. In the absence of a reconciliation between Indigenous and other Australians, it is likely to continue to do so.

\section{Indigenous Australia as a Tourist Drawcard}

In 2003, the then Australian Tourist Commission, now Tourism Australia, produced a report summarising research conducted specifically into Aboriginal tourism and the Aboriginal tourism segment (Australian Tourist Commission, 2003). Given Australia's recent focus on Indigenous identity in its tourism branding, the findings contained within this report make for insightful reading. Broad conclusions from the various research studies reviewed were:

Overall, Aboriginal tourism experiences for most visitors were regarded as desirable but did not drive destination choice or holiday itinerary planning.

$\square$ Interaction and authenticity were important aspects of an Aboriginal tourism experience. Visitors to Indigenous tourism product were typically keen to learn, to experience and interact with the Aboriginal people.

$\square$ Western markets (the United Kingdom and Europe in particular) hold most potential overall for Aboriginal tourism, with higher levels of awareness, interest and participation.

Table 2 provides a summary of the percentage of visitors who reported being influenced by Aboriginal culture in making the decision to visit Australia (Australian Tourist Commission, 2003). These results indicate that participation in Aboriginal product from international visitors was highest amongst Western markets: Germany, United Kingdom, Other Europe, Canada and the USA. Unfortunately, by and large, these are the same market segments that have shown a drop-off in visitation to Australia in recent years, yet, paradoxically, they remain key markets for Tourism Australia's promotional efforts. Ironically, recent increases in visitor numbers have 
largely been seen from markets displaying the least interest in interacting with Indigenous Australia (Tourism Australia, 2011).

\section{Insert Table 2 here}

\section{Conclusion}

The purpose of this paper was to discuss Australia's recent attempt at nation branding by featuring elements of Indigenous identity in its international tourism advertising campaign, and to discuss reasons for why this branding approach has possibly achieved sub-optimal results. The advertising campaigns discussed briefly in this article have been strategically inconsistent and tended to rely on culturallysubordinating depictions of Indigenous identity that are at odds with the factual identity of Indigenous Australia.

Our approach has the obvious limitation that we are reporting secondary data to support our theses that, firstly, Indigenous identity-based nation branding is a fraught strategy when that identity is, at best, a contested one, and, second, that branding consistency is a necessity for successful brand positioning. Despite this recourse to secondary data, we believe we make a contribution in highlighting some of the pitfalls in Indigenous identity-based nation branding, especially when tension surrounds this identity.

Australia's Come Walkabout advertising campaign risked being ineffective on two fronts. First, it was a radical departure from the previous marketing communications 
approach, and therefore it was likely to promote confusion in the minds of audiences searching for a clear, consistent, and agreeable image of Australia's identity as a holiday destination. Second, campaign audience members that already held knowledge of Indigenous identity in Australia, based on either their prior experience with the nation or negative media coverage in relation to management of Indigenous issues, such as Black Deaths in Custody, may have found such advertising incongruous with already held beliefs. As O'Shaughnessy and O'Shaughnessy (2000) note, "the observer-dependent image of a nation cannot be divorced from some core of observer-independent facts" (p. 63).

A key element of a successful marketing communications strategy is the communication of a consistent brand positioning; repositioning of a brand, as discussed here in the case of Australia, is extremely difficult. Moving from a humorous, colloquial advertising appeal to a more sophisticated, cinematic and narrative approach, using a different tone and message, is a high-risk approach at best. The danger inherent in such inconsistency is explained by such informationprocessing theories as dissonance theory (Festinger, 1957) and cognitive response theory (Wright, 1973), summarized broadly as suggesting that new informational inputs will be scrutinized in relation to already held attitudes and beliefs.

\section{Indigenous-based Australian Tourism}

Tourism Australia defines an Indigenous tourism visitor as "one who participates in at least one Indigenous tourism activity during their trip...The definition of an international Indigenous tourism visitor also includes attending an Aboriginal performance" (Department of Resources, Energy and Tourism, 2011). Australia's 
tourism industry leaders' view of Indigenous Australians' potential contribution to the nation's tourism industry seems to have moved on little since Harris et al.'s 1966 report. The following is taken from a recent Australian Government, Department of Resources, Energy and Tourism Indigenous Tourism Visitors in Australia Report (2011):

Australia's Indigenous culture is a key point of differentiation in a highly competitive international tourism market. Australia's Indigenous tourism experiences are one of the seven key experiences which underpin Tourism Australia's global marketing activities. Under the National Long-Term Tourism Strategy, Australian Tourism Ministers have established the Indigenous Tourism Development Working Group, chaired by Tourism NT, to examine ways to improve the quality and quantity of Australia's Indigenous tourism product offering and to maximise the participation of Indigenous Australians in the tourism industry.

Research reported in 2003 that interested visitors claimed there was little promotion of Aboriginal tourism in Australia: "Between $60-80 \%$ of interested visitors claimed that they saw 'little' or 'no' promotion of Aboriginal tourism while in Australia. Although experienced visitors recorded higher levels of promotion of Aboriginal tourism opportunities while in Australia, at least half still claimed there was little or no such promotion" (ATC, 2003). Unfortunately, the same report notes that international Indigenous tourist visitors, as defined above, have seen a steady decline of around 25 percent since 2005. It would appear the Working Group, mentioned above, has much to do to arrest this fall.

\section{A Need to Reconcile Indigenous Australian Identity with Australian Identity}

How Indigenous Australian identity might be promoted in the nation's branding in a manner that demonstrates respect for these Australians and projects an acceptable level of extraordinariness to be authentic and yet palatable to international audiences 
is a difficult question, and one beyond the scope of this paper. The answer is probably tied up within the notion of reconciliation, a concept still some way off in the psyche of an increasingly multi-cultural contemporary Australia. Yet this is an important question for Australia's tourism brand managers. Future research might investigate international consumers' awareness of contemporary Indigenous Australian issues in order to examine whether this awareness is, of itself, an obstacle to visiting Australia, or whether it might override extraordinary portrayals of the fragments of Indigenous Australian identity of contemporary tourism branding. Such research has been called for in a recent article by Pomering and White (2011).

Some recent celebrations in Australia have offered an opportunity for celebration of Indigenous Identity, such as the Sydney Olympics in 2000 and Australia's Centenary of Federation in 2001, but the longer-term negative impacts of such problems as the need for reconciliation and Aboriginal land rights, black deaths in custody, the stolen generation, housing, education, unemployment and health, the metrics on which Indigenous Australia continue to do much worse than the dominant Australian community, tend to eclipse these one-off, landmark opportunities. Representing Australia's true Indigenous identity, if it is to exist beyond a sub-brand of Australia's brand architecture, requires a much deeper understanding and more accurate identity portrayal than simply sprinkling pixie dust and encouraging weary executives, worn down from the rituals of their ordinary worlds, to come on an extraordinary Walkabout. 


\section{References}

Anderson, B. (1983) Imagined communities: Reflections on the origin and spread of nationalism. London: Verso.

Anholt, S. (2004) Nation brands and the value of provenance. In: N. Morgan, A. Pritchard, and R. Pride (eds.) Destination branding: Creating the unique destination branding proposition (second edition). Oxford: Butterworth-Heinemann, pp. 26-39.

Anholt, S. (2007) Competitive identity: The new brand management for nations, cities and regions. Basingstoke: Palgrave Macmillan.

Anholt, S. (2010) Places, identity, image and reputation. Basingstoke: Palgrave Macmillan.

Appadurai, A. (1996) Modernity at large: Cultural dimensions of globalization. Minneapolis: University of Minnesota Press.

Australian Broadcasting Commission. (2009) Tourism Australia looks beyond 'controversial campaign'. Australian Broadcasting Commission report, http://www. abc.net.au/news/2008-02-07/tourism-australia-looks-beyond-controversial/1036344, accessed 17 May 2011.

Australian Broadcasting Commission. (2009) UN labels Indigenous intervention racist. Australian Broadcasting Commission report, 27 August, http://www.abc. net.au/lateline/content/2008/s2669184.htm, accessed 5 October 2011.

Australian Human Rights Commission. (2008) A statistical overview of Aboriginal and Torres Strait Islander peoples in Australia. Australian Human Rights Commission report, http://www.hreoc.gov.au/social_justice/statistics/index. html, accessed 20 July, 2011.

Australian Bureau of Statistics. (2012) Overseas Arrivals and Departures. Australian Bureau of Statistics report, http://www.abs.gov.au/ausstats/abs@.nsf/mf/3401.0, accessed 9 February 2012.

Australian Tourist Commission, Segment Insights Pack: Market Research Intelligence on Aboriginal Tourism (2003). Canberra: Australian Tourist Commission.

Bennett, T. (1993) The shape of the past. In: G. Turner (ed.) Nation, culture, text: Australian cultural and media studies. London: Routledge, pp. 72-90.

Bureau of Tourism Research. (2003) International Visitors in Australia, 1999-2002. Bureau of Tourism Research (Commonwealth of Australia, Canberra) report, http://www.ret.gov.au/tourism/Documents/tra/International\%20Visitor\%20Survey/IV S\%20Annual\%201999-2002.pdf, accessed 5 June 2011. 
Chernatony, L. and MacDonald, M. (2003) Creating powerful brands in consumer, service and industrial markets (third edition). Oxford: Butterworth-Heinemann.

Craik, J. (2001) Tourism, culture and national identity: Policies, publics and programs. In: T. Bennett and D. Carter (eds.) Culture in Australia. Cambridge: Cambridge University Press, pp. 89-113.

Department of Resources Energy and Tourism. (2011) Tourism Industry Facts \& Figures at a Glance. Department of Resources Energy and Tourism report, May 2011, http://www.ret.gov.au/tourism/Documents/Tourism\%20Statistics/2011/At-a-glanceMay\%202011.pdf, accessed 20 September 2011.

Dwyer, L. (2010) Riding the Tourism Waves: Can the Real Australia Please Stand Up?Knowledge@Australian School of Business, http://knowledge.asb.unsw. edu.au/article.cfm?articleid=1142, accessed 20 March, 2011.

Festinger, L. (1957) A theory of cognitive dissonance. Evanston, Illionois: Row Peterson.

Harris, Kerr, Forster and Co., (1966) Australia's travel and tourism industry 1965. Report commissioned by Australian National Travel Association. Sydney: Stanton Robins and Co.

Harris, Kerr, Forster and Co. (1969) Ayers Rock - Mt Olga National Park:

Development Plan. Report to Northern Territory Reserves Board. Honolulu: Harris, Kerr, Forster and Co.

Hummon, D.M. (1988) Tourist worlds: Tourist advertising, ritual, and American culture, Sociological Quarterly 29(2): 179-202.

Macrae, C., Parkinson, S. and Sheerman, J. (1995) Managing marketing's DNA: The role of branding. Irish Marketing Review 18: 13-20.

Morgan, N. and Pritchard, A. (1998) Tourism promotion and power: Creating images, creating identities. Chichester: Wiley.

Morgan, N., Pritchard, A. and Piggott, R. (2002) New Zealand, 100\% pure: The creation of a powerful niche destination brand. Brand Management 9(4-5): 335-354.

Morgan, N., Pritchard, A. and Pride, R. (2004) Destination branding: Creating the unique destination proposition (second edition). Oxford: Butterworth-Heinemann.

Nationmaster. (2011) International Tourists: Number of Arrivals by Country. Nationmaster.com report, http://www.nationmaster.com/graph/eco_int_tou_ num_of_arr-economy-international-tourism-number-arrivals, accessed 5 October 2011.

New Zealand History. (2011), Making the Treaty of Waitangi. New Zealand History report, http://www.nzhistory.net.nz/politics/treaty/read-the-treaty/drafting-the-treaty, accessed 20 July 2011. 
O'Shaughnessy, J. and O'Shaughnessy, N.J. (2000) Treating the nation as a brand: Some neglected issues. Journal of Macromarketing, 20 (1): 56-64.

Pannell, Kerr, Forster and Company (1971) Great Barrier Reef: Visitor Plan Melbourne: Pannell, Kerr, Forster and Co: Australian Tourist Commission.

Pitchford, S. (2008) Identity tourism: Imagining and imaging the nation. Bingley, UK: Emerald Group Publishing.

Pomering, A. and White, L. (2011) The portrayal of Indigenous identity in Australian tourism brand advertising: Engendering an image of extraordinary reality or staged authenticity?, Place Branding and Public Diplomacy 7(3): 165-174.

Snape, D. and Spencer, C. (2006) The foundations of qualitative research. In J. Ritchie and J. Lewis (Eds.), Qualitative research practice: A guide for social science students and researchers. London: Sage Publications, pp. 1-23.

Studies in Australia. (2011) The International Students Guide. Studies in Australia report, http://www.studiesinaustralia.com/studying-in-australia/why-study-inaustralia/international-students-in-australia, accessed 27 September, 2011.

Sydney Morning Hearld. (2008) 'Bloody hell' ad rolled gold disaster: PM. The Sydney Morning Herald, 24 June, http://www. smh.com.au/news/travel/bloody-hell-ad-rolledgold-disaster-pm/2008/06/24/1214073233308.html, accessed 27 September, 2011.

Taylor, P.J. (2001) Which Britain? Which England? Which north? In: D. Morely and K. Robins (eds.) British Culture Studies. Oxford: Oxford University Press.

Tourism Australia. (2008) New campaign to inspire Australians to holiday in Australia. Tourism Australia media release, http://www.media.australia. com/en-au/mediareleases/3535.aspx, accessed 3 June 2010.

Tourism Australia. (2009) Tourism Australia Fact Sheets, Walkabout. Tourism Australia report, http://www. Media.australia.com/en-au/factsheets/default_1438. aspx, accessed 27 September 2011.

Tourism Australia. (2009a) Tourism Australia Annual Report 2008-9. Tourism Australia report, http://www.tourism.australia.com/en- au/documents/Corporate About Us/Annual_Report_2008_2009.pdf, accessed 20 August 2011.

Tourism Australia. (2011) Tourism Australia Visitor Arrivals, December 2010. Tourism Australia report, http://www.tourism.australia.com/en-au/research/ 5236_6181.aspx, accessed 5 February 2012.

Urry, J. (1992) The tourist gaze "revisited". American Behavioral Scientist 36(2): 172-186.

Van Rekom, J. (1997) Deriving an operational measure of corporate identity. European Journal of Marketing 31(5/6): 410-422. 
Wright, P.L. (1973) The cognitive processes mediating acceptance of advertising. Journal of Marketing Research 10: 53-62. 
Table 1: Tourist Arrivals in Australia v. Globe, 2000 - 2010

\begin{tabular}{|c|c|c|c|}
\hline Year & $\begin{array}{c}\text { Arrivals } \\
\text { (nearest } \mathbf{0 0 0})\end{array}$ & $\begin{array}{c}\text { Global Tourism Arrivals } \\
\text { (nearest } \mathbf{0 0 0 , 0 0 0 )}\end{array}$ & $\begin{array}{c}\text { Global Arrivals Change } \\
\text { (\%) }\end{array}$ \\
\hline 2000 & $4,931,000$ & & 0.0 \\
\hline 2001 & $4,856,000$ & 675 & 3.0 \\
\hline 2002 & $4,841,000$ & 695 & -1.6 \\
\hline 2003 & $4,746,000$ & 684 & 10.4 \\
\hline 2004 & $5,215,000$ & 755 & 5.7 \\
\hline 2005 & $5,499,000$ & 798 & 5.5 \\
\hline 2006 & $5,532,000$ & 842 & 6.7 \\
\hline 2007 & $5,644,000$ & 898 & 2.1 \\
\hline 2008 & $5,586,000$ & 917 & -3.8 \\
\hline 2009 & $5,584,000$ & 882 & 6.6 \\
\hline 2010 & $5,900,000$ & 940 & \\
\hline
\end{tabular}

Sources: United Nations World Tourism Organization, World Tourism Barometer, February 2011 and April 2011, and Nationmaster.com 2011.

Australian Government, Department of Resources, Energy and Tourism, Tourism Research Australia, Facts \& Figures at a Glance, May 2011.

Table 2 Visitors were influenced by Aboriginal culture in making the decision to come to Australia (percent)

\begin{tabular}{|l|c|c|c|}
\hline Country of Residence & $\begin{array}{l}\text { \% Of Visitors from } \\
\text { each country where to } \\
\text { experience Aboriginal } \\
\text { culture influenced } \\
\text { decision to come to } \\
\text { Australia }\end{array}$ & $\begin{array}{l}\text { \% Of Visitors from } \\
\text { each country who } \\
\text { experienced } \\
\text { Aboriginal art/craft } \\
\text { and cultural displays }\end{array}$ & $\begin{array}{l}\text { \% Of Visitors from } \\
\text { each country who } \\
\text { visited an Aboriginal } \\
\text { site/community }\end{array}$ \\
\hline New Zealand & 1 & 4 & 1 \\
\hline Japan & 2 & 8 & 3 \\
\hline Hong Kong & 1 & 6 & 1 \\
\hline Singapore & 3 & 3 & 1 \\
\hline Malaysia & 2 & 5 & 1 \\
\hline Indonesia & 1 & 4 & 1 \\
\hline Taiwan & 3 & 9 & 1 \\
\hline Thailand & 2 & 5 & 2 \\
\hline Korea & 0 & 3 & 1 \\
\hline China & 6 & 4 & 8 \\
\hline Other Asia & 1 & 6 & 10 \\
\hline USA & 4 & 16 & 11 \\
\hline Canada & 4 & 20 & 19 \\
\hline UK & 6 & 18 & \\
\hline Germany & 18 & 32 & \\
\hline
\end{tabular}




\begin{tabular}{|l|c|c|c|}
\hline Other Europe & 9 & 20 & 13 \\
\hline Other Countries & 2 & 6 & 3 \\
\hline Total & 4 & 10 & 5 \\
\hline
\end{tabular}

Base: All visitors aged 15 years and over

Source: Bureau of Tourism Research, International Visitor Survey, 2003.

Other Europe includes approximately 30 European countries (excluding Germany and the United Kingdom) 